\title{
PENEGAKKAN HUKUM ALIRAN SESAT DI INDONESIA TINJAUAN UNDANG \\ UNDANG PNPS NO.1 TAHUN 1965 TENTANG PENCEGAHAN \\ PENYALAHGUNAAN DAN/ATAU PENODAAN AGAMA
}

\author{
Emy Hajar Abra \\ Dosen Tetap Prodi Ilmu Hukum Universitas Riau Kepulauan Batam
}

\begin{abstract}
ABSTRAK
Aliran sesat menjadi problematic tersendiri dalam penegakkan hukum di Indoensia. Undang Undang PNPS No 1 Tahun 1965 tentang Penyalahgunaan dan/atau Penodaan Agama yang sudah sekian lama hadir, nyatanya belum mampu dimaknai dengan bijak oleh banyak kalangan. Permasalahan kemudian muncul, ketika para pihak yang mengajukan judicial review ke Mahkamah Konstitusi dan mengatakan bahwa undang undang tersebut telah melanggar Konstitusi. Sekalipun permohonan yang di ajukan oleh para pihak ditolak oleh Majelis Hakim Konstitusi, namun yang sering kali dilupakan adalah bahwa negara kita adalah negara hokum, hal tersebut dengan tegas dituangkan UUD 1945 pasal 1 ayat 3, artinya bahwa tiap individu tanpa terkecuali harus tunduk pada tiap aturan yang berlaku. Selain itu, yang menjadi dasar argument bagi mereka yang kontra terhadap undang undang aliran sesat adalah, Hak Asasi Manusia. Mereka yang tidak setuju terhadap undang undang aliran sesat, seringkali berargumen bahwa undang undang tersebut telah melanggar hak asasi seseorang, nyatanya pasal 28J UUD 1945 membatasi kebebasan tersebut dengan sangat bijak. Maka bebas itu bukan tanpa batas sebagaiman ditafsirkan, namun Undang Undang dihadirkan sebagai pagar pembatas demi terciptanya keadilan dalam bernegara.
\end{abstract}

\section{PENDAHULUAN}

\section{A. Latar Belakang Masalah}

Kasus aliran sesat memang tidak begitu marak seperti beberapa tahun lalu, sekalipun demikian, tulisan ini hadir dalam bentuk "kehatia-hatian" hukum, karena biar bagaimanapun, kasus aliran sesat sudah semestinya menjadi perhatian tersendiri, mengingat hal ini berhubungan dengan kebebasaan beragama dan keharmonisan dalam bernegara. Pasalnya penodaaan agama bukan kasus yang datang dan tenggelam. Peristiwa ini ada, hanya saja dia muncul dipermukaan ketika telah menjadi kekerasan atau bahkan menelan korban. Oleh karena itu, penulis menggunakan kata "kehati-hatian" hukum, karena peristiwa ini harus dimaknai 
serius oleh pemerintah dan aparat penegak hukum, untuk dapat bergerak lebih cepat sebelum adanya konflik yang berkepanjangan. Selain itu pula, kehati-hatian hokum tersebut mengingat banyak pihak yang pro dan kontra sejak dari awal pembentukan Undang Undang PNPS No 1 Tahun 1965 ini hingga sekarang.

Pada penjelasan Undang Undang No1 tahun 1965 menjelaskan bahwa, hadirnya undang-undang ini atas kegelisahan bermunculannya aliran-aliran kepercayaan yang menganggu agama lain, oleh karenanya pemerintah merasa perlu dalam menjaga kemurnian dan kebebasan beragama yang kemudian pembatasannya di atur dalam Undang Undang. Jika dilihat dari politik hukum Undang Undang tersebut, maka jelas bahwa pemerintah menaruh perhatian yang sangat baik atas perlindungan agama., agar tidak disimpangi oleh ajaran-ajaran lain yang keluar dari ajaran pokok suatu agama tertentu.

Sekalipun Indonesia menganut system politik yang demokratis, namun tidak menjadikan nilai-nilai demokrasi itu berjalan tanpa payung hukum yang kuat. Konflik agama yang sering terjadi dan berkembang ini tentunya membutuhkan perhatian khusus dari pemerintah dan juga tentunya masyarakat sebagai salah satu pelaku dalam bernegara. Kejadian aliran kepercayaan yang terus-menerus dan memakan korban yang tidak sedikit tentunya bukan hal yang patut dibiarkan berlarut-larut. Apalagi dari kejadian ini justru menjadikan masyarakat bermain hakim sendiri, seperti pada pembakaran rumah masyarakat, tempat ibadah, bahkan pembunuhan, keadaan main hakim sendiri tersebut, memaknai bahwa fungsi negara sudah mulai menghilang. Penyimpangan agama yang kemudian lebih dikenal dengan sebutan aliran sesat ini, semakin tahun justru berkembang semakin banyak. Fakta ini bisa dilihat dari bermunculnya aliran sesat di masyarakat. Sejak 2001 hingga 2007, sedikitnya ada 250 aliran sesat yang berkembang di Indonesia. 50 Di antaranya tumbuh subur di Jawa Barat. ${ }^{1}$

Hal ini merupakan bagian paling hitam dari perkembangan agama. Penulis menggunakan kata bagian "paling hitam”, karena penyebaran agama yang jauh dari pada pokok dasarnya ini menimbulkan banyak goncangan di masyarakat. Misalnya pada masyarakat luas, mereka telah mempercayai salah satu agama tertentu, tiba-tiba didatangi oleh orang atau sekelompok orang yang mengaku se-agama, namun dengan pemahaman dan pelaksanaan yang jauh berbeda dari pokok ajaran tersebut. Tentunya itu menjadi goncangan yang dapat berakibat luas pada keharomonisan bermasyarakat dan bernegara. Oleh karenanya selain dari pada

\footnotetext{
${ }^{1}$ Maraknya Aliran Sesat Mirip Prolog G30S PKI Tahun 1965 _Http://Hariansib.Com /2007/11/01/ Maraknya Aliran-Sesat-Mirip-Prolog-G30s-Pki-Tahun-1965/
} 
Undang Undang tentang aliran sesat, kiranya penting pemerintah untuk mengatur mengenai tata cara dan akibat-akibat hukum jika suatu ajaran mempunyai definisi atau cara beragama yang berbeda dari yang di akui pada kebanyakan masyarakat lainnya.

Sekitar akhir tahun 2009 lalu, beberapa kalangan mengajukan gugatan atau permohonan judicial review UU No 1/PNPS/1965 tentang Penyalahgunaan dan/atau Penodaan Agama ke Mahkamah Konstitusi. Para pemohon tersebut antara lain: LSM Imparsial, Elsam, PBHI, Demos, Setara, Desantara, YLBHI dan Pemohon perorangan, diantaranya: Abdurahman Wahid, Musdah Mulia, Dawam Rahardjo, dan Maman Imanul Haq, namun kemudian dalam putusannya, permohonan tersebut di tolak secara keseluruhan oleh Majelis Hakim Konstitusi.

Penolakan tersebut tentunya menjadi sejarah tersendiri bagi ketatanegaraan Indonesia, khususnya dalam bidang keagamaan, hal ini karena Undang Undang yang sudah cukup lama itu, justru masih berlaku dan mendapatkan perhatian yang baik dalam pernafsirannya oleh majelis hakim kosntitusi, sehingga majelis menilai bahwa, undang undang tersebut masih berlaku dan konstitusional artinya tidak bertentangan dengan UUD 1945.

\section{B. Rumusan Masalah}

Berdasarkan latar belakang masalah di atas, maka di dapat rumusan permasalahannya adalah sebagai berikut:

1. Bagaimana politik hukum Undang Undang PNPS No 1 Tahun 1965, tentang Pencegahan Penyalahgunaan dan/atau Penodaan Agama.

2. Bagaimana pula penegakkan hukum Undang Undang PNPS No 1 tahun 1965 , terkait aliran sesat di Indonesia.

\section{PEMBAHASAN}

\section{A. Definisi Aliran Sesat}

Beberapa kepercayaan yang menjamur di dalam masyarakat bukanlah hal yang baru, bahkan seperti Ahmadiyah misalnya sudah lahir pada abad 20. Aliran sesat, berasal dari dua 
suku kata, yakni aliran dan sesat, aliran adalah bergerak maju, meleleh, berpindah tempat, dan kata yang seiring yaitu, mazhab, paham, sekte, sedangkan sesat adalah salah, keliru, menyimpang dari kebenaran, padanan kata asingnya yaitu dalal atau bid'ah. ${ }^{2}$ Maka aliran sesat adalah suatu aliran atau sekte yang bergerak untuk menyebarkan suatu faham tertentu yang pada dasarnya sudah keluar dari ajaran suatu agama tertentu. Menurut Hasyim adanya aliran sesat mirip saat masa prolog G30S PKI pada tahun 1964-1965. ${ }^{3}$

Untuk negara Indonesia maka MUI adalah salah satu lembaga kegamaan dalam hal ini islam yang mempunyai wewenang untuk mengeluarkan fatwa dan juga dapat menjadi acuan umat islam di Indonesia dalam beragama. MUI juga ketika mengeluarkan pendapat yang kemudian di kenal dengan fatwa terebut, tidak menjadi wajib hukumnya untuk dikuti oleh umat islam di Indonesia, namun fatwa itu dapat menjadi rujukan hukum islam bagi masyarakat dan tak menutup kemungkinan dalam hal ini negara Indonesia juga menjadikannya sebagai rujukan hukum dalam pembuatan perundang-undangan.

MUI dalam ketatanegaraan memang bukan merupakan lembaga pemerintahan ataupun lembaga dalam konsep trias politika, namun keberadaan MUI sudah menjadi pengetahuan umum bahwa, fatwa yang dikeluarkan kemudian, adalah menjadi salah satu sumber hukum atau rujukan hukum dalam bidang keagamaan. Bahkan agama islam yang dianaut lebih dari $85 \%$ rakyat Indonesia dapat menjadi sumber hokum sekalipun bukan sumber hukum formil namun sebagai sumber hukum materiil. ${ }^{4}$

Adapun beberapa aliran yang menjadi pusat perhatian masyarakat pada beberapa tahun terakhir misalnya:

1. Kerajaan tuhan Eden yaitu Lia Aminudin yang mengaku sebagai Jibril Ruhul Kudus dari kerajaan Tuhan "Eden".

2. Munculnya aliran sesat al-Qiyadah al-Islamiyah. Para pengikutnya adalah orangorang yang merasa kehilangan harapan ke depan sehingga kemunculan tokoh seperti Ahmad Mushaddeq memang ditunggu-tunggu mereka. Mushaddeq punya pemahaman dan keyakinan sendiri sehingga akhirnya mengaku telah mendapatkan wahyu kerasulan melalui mimpi dan mengaku menerima wahyu setelah berpuasa

\footnotetext{
${ }^{2}$ Kamus Besar Bahasa Indonesia, Balai Pustaka. Jakarta. 1990. Hlm 22,836

3 Maraknya Aliran Sesat Mirip Prolog G30S PKI Tahun 1965 Http://Hariansib.Com 2007/11/01/ Maraknya Aliran-Sesat-Mirip-Prolog-G30s-Pki-Tahun-1965/

${ }^{4}$ Moh Mahfud MD, Membagun Politik Hukum, Menegakkan Konstitusi, Jakarta: Rajawali Pers, 2010, Hlm 100
} 
siang-malam selama 40 hari. Selanjutnya, dia mendirikan al-Qiyadah al-Islamiyah dan mengaku sebagai rasul bergelar al-Masih al-Maw'ud. ${ }^{5}$

3. Aliran pengajian Qur'an suci, diduga telah mengakibatkan hilangnya mahasiswamahasiswi pada saat itu. Sejak 9 September 2007, Cara perekrutan jamaah pengajian "al-Qur`an Suci" dilakukan dengan sistem berantai atau mirip Multi Level Marketing (MLM). Jamaah yang sudah masuk, diwajibkan mengajak orang lain lagi untuk masuk ke kelompok itu. Begitu seterusnya, mirip system penjualan MLM. Jamaah yang direkrut harus pintar, pemikir dan pendiam. ${ }^{6}$ Serta aliran-aliran lainnya yang tersebar luas di Nusantara.

Pada tanggal 9 November 2007, Majelis Ulama Indonesia (MUI) telah mengeluarkan 10 kriteria aliran sesat, diantaranya: ${ }^{7}$

a. Mengingkari rukun iman (Iman kepada Allah, Malaikat, Kitab Suci, Rasul, Hari Akhir, Qadla dan Qadar) dan rukun Islam (Mengucapkan 2 kalimat syahadah, sholat 5 waktu, puasa, zakat, dan Haji)

b. Meyakini dan atau mengikuti akidah yang tidak sesuai dalil syar`i (Alquran dan assunah),

c. Meyakini turunnya wahyu setelah Alquran

d. Mengingkari otentisitas dan atau kebenaran isi Alquran

e. Melakukan penafsiran Alquran yang tidak berdasarkan kaidah tafsir

f. Mengingkari kedudukan hadis Nabi sebagai sumber ajaran Islam

g. Melecehkan dan atau merendahkan para nabi dan rasul

h. Mengingkari Nabi Muhammad SAW sebagai nabi dan rasul terakhir

i. Mengubah pokok-pokok ibadah yang telah ditetapkan syariah

j. Mengkafirkan sesama Muslim tanpa dalil syar'i.

\section{B. Definisi Politik Hukum}

\footnotetext{
${ }^{5}$ Menyikapi Al-Qiyadah Al-Islamiyah Http://Www.Cmm.Or.Id /Cmm-Ind_More .Php ? Id=4928_0_3_0_C ${ }^{6}$ Pengajian Alquran Suci Jaring Jamaah Mirip MLM, Erna Mardiana - Detikcom Http://Www.Detiknews.Com /Index.Php/Detik.Read/Tahun/2007/Bulan/10/Tgl/04 /Time /123032/Idnews/837829/Idkanal/10

${ }^{7}$ MUI: 10 (Sepuluh) Kriteria Aliran Sesat Http://Www.Media-Islam.Or.Id /2007/11/09/Mui-Sepuluh-KriteriaAliran-Sesat/
} 
Prof Saldi Isro dalam sebuah kesempatan perkuliahaan mengatakan bahwa, politik hukum itu ibarat "mata-hari" (matahari). ${ }^{8}$ Artinya bahwa kedua kosa kata tersebut tak bisa dipisahkan satu sama lain dan menjadi satu kesatuan yang utuh. Sedangkan menurut Mahfud MD, Politik hukum adalah legal policy atau arah hukum yang akan diberlakukan oleh Negara untuk mencapai tujuan Negara yang bentuknya dapat berupa pembuatan hukum baru dan pergantian hukum lama, dalam artian bahwa politik hukum itu harus berpijak pada tujuan Negara dan system hukum yang berlaku di Negara yang bersangakutan dalam konteks Indonesia dan system itu terkandung dalam pancasila dan pembukaan UUD. ${ }^{9}$

Politik hukum menurut Teuku Muhammad Radhie adalah sebagai pernyataan kehendak penguasa Negara mengenai hukum yang berlaku diwilayahnya dan mengenai arah perkembangan hukum yang di bangun. Padmo Wahjono mengatakn bahwa politik hukum itu kebijakan dasar yang menentukan arah, bentuk, maupun isi hukum yang akan di bentuk. ${ }^{10}$

Politik hukum itu mengenai legal policy, dalam hal ini ketika negara membuat suatu kebijakan hukum tentunya mempunyai alasan yang mendasari dari lahirnya aturan tersebut. Hal inilah yang kemudian harus di pahami dengan bijak oleh masyarakat, bahwa hukum yang dibuat atau yang pada kemudian hari di judisial review namun dinyatakan masih berlaku adalah bentuk tafsiran normative yang konstitusional.

Maka dalam Undang Undang No 1 tahun 1965, Majelis Hakim Konstitusi menilai bahwa, UU penodaan agama tersebut masih tetap sah secara formil, MK juga tak sependapat jika UU yang dibuat pada masa demokrasi terpimpin itu semua tidak sah dan cacat proses pembentukannya. MK juga tidak sependapat jika UU Penodaan Agama itu tidak sesuai dengan UUD 1945. MK memberikan pandangannya bahwa, pasal 1 UU Penodaan Agama ini memberikan kepastian pada setiap orang dilarang yang dengan sengaja menyebarkan dan menganjurkan untuk melakukan penafsiran terhadap kegiatan yang menyimpang dari pokok agama.

\section{Kedudukan Hak Asasi Manusia Dalam Aliran Sesat}

\footnotetext{
${ }^{8}$ Saldi Isro Dalam Perkuliahan Politik Hukum, Pascasarjana UII, Yogyakarta, 2011

${ }^{9}$ Moh Mahfud MD. Membangun Politik Hukum Dan Menegakkan Konstitusi, Jakarta, Rajawali Pers, 2010, Hlm 5

${ }^{10}$ Moh. Mahfud Md, "Politik Hukum Di Indoensia”, Jakarta, PT Raja Grafindo Persada, 2012, Hlm 1
} 
Sejumlah kalangan yang meminta agar MUI mencabut fatwanya tentang beberapa aliran sesat, hingga pada tuntutan agar MUI dibubarkan, biasanya meletakkan dasar argumennya pada kebebasan yang termuat dalam Undang Undang Hak Asasi Manusia. Sama halnya dengan tuntutan agar Undang Undang No 1 tahun 1965 dicabut, mereka yang mengajukan permohonannya ke MK, sering kali mendalilkan semua kejadiannya atas nama HAM.

Perlu diingat bahwa dalam Undang Undang HAM pasal 67 UU No 39 tahun 1999 menyatakan bahwa, "Setiap orang yang ada di wilayah negara Republik Indonesia wajib patuh pada peraturan perundang-undangan, hukum tak tertulis, dan hukum internasional mengenai hak asasi manusia yang telah diterima oleh negara Republik Indonesia.”

Hal tersebut dipertegas dalam pasal 70, UU No 39 Tahun 1999, bahwa: "Dalam menjalankan hak dan kebebasannya, setiap orang wajib tunduk kepada pembatasan yang ditetapkan oleh undang-undang dengan maksud untuk menjamin pengakuan serta penghormatan atas hak dan kebebasan orang lain dan memenuhi tuntutan yang adil sesuai dengan pertimbangan moral, keamanan, dan ketertiban umum dalam suatu masyarakat yang demokrati”.

HAM yang menjadi pokok dasar permohonan itu ternyata memiliki kekuatan hukum yang terbatas, tidak bebas tanpa batas sebagaimana yang ditafsirkannya, sehingga menginginkan agar Undang Undang No 1 tahun 1965 dicabut. Hal tersebut menjadikan pemahaman tersendiri bahwa, pemaknaan kebebasan itu tidak serta merta "bebas" tanpa Norma lain yang mengatur, itulah kenapa ketundukan hukum oleh setiap pribadi adalah menjadi hal yang utama.

\section{Pandangan Hukum Undang Undang Nomor 1 Tahun 1965}

Ada beberapa hal yang melatarbelakangi Lahirnya Undang-Undang PNPS Nomor 1 Tahun 1965, diantaranya adalah:

1. Sila pertama pancasila, "Ketuhanan Yang Maha Esa", yang tidak dapat dipisahkan dari agama dan merupakan landasan moral, dan landasan konstitusional Indonesia.

2. Bahwa kebebasan beragama yang diberikan dalam undang-undang adalah memiliki pemaknaan pembatasan yang dijabarkan dalam Undang Undang.

3. Munculnya berbagai macam aliran-aliran kepercayaan yang meresahkan masyarakat pada umumnya. 
4. Aliran-aliran atau organisasi-organisasi kebatinan /kepercayaan masyarakat tersebut bertentangan dengan ajaran-ajaran dan hukum agama tertentu.

5. Aliran-aliran tersebut pada akhhirnya menimbulkan pelanggaran hukum, memecah persatuan nasional dan menodai kesucian agama lainnya.

6. Menyalahgunaan dan mempergunakan agama sebagai pokok yang membahayakan atau menodai agama-agama yang sudah ada.

Memahami situasi di Indonesia bukanlah hal mudah, Indonesia memiliki keaneka ragaman sejarah, budaya, suku, dan agama yang begitu komplek. Problematika masyarakat bisa diobservasi, tetapi tidak bisa diperlakukan sebagaimana obyek yang mati, adakalnya reaksi yang ditimbulkan akibat adanya suatu investigasi tidak mudah diukur validitasnya, sehingga obeyktifitas dari informasi yang diperoleh secara pasti, konsistensi dan koheren tidak semudah data kealaman yang dikumpulkan melalui suatu proses dan metode penelitian tertentu. ${ }^{11}$

Salah satu hakim MK Arsyad juga menegaskan bahwa negara boleh membatasai kebebasan sesuai dengan UUD dan tunduk kepada pembatasan atas penghormatan hak asasi orang lain berdasarkan nilai agama dan sesuai dengan bentuk negara demokratis. Negara memberikan kewajiban dasar atas tegaknya HAM. Secara integral UUD mengatur setiap elemen negara dan masyarakat untuk menghormati HAM itu sendiri. Hal itu harus berlaku dan dilaksanakan dan tanpa melukai yang lainnya. ${ }^{12}$

Indonesia adalah negara yang berdasarkan pancasila dan menempatkan hukum sebagai peranan penting. Pasal 29 ayat (1) dan (2) Undang-undang Dasar 1945 menyatakan bahwa Negara berdasarkan Ketuhanan yang Maha Esa, serta menjamin kemerdekaan tiap-tiap penduduk untuk memeluk agamanya masing-masing dan untuk beribadat menurut agama dan kepercayaannya. Lebih lanjut Pasal $28 \mathrm{~J}$ ayat 2 menyatakan dengan tegas bahwa, "Dalam menjalankan hak dan kebebasannya, setiap orang wajib tunduk kepada pembatasan yang ditetapkan dengan undang-undang dengan maksud semata-mata untuk menjamin pengakuan serta penghormatan atas hak dan kebebasan orang lain dan untuk memenuhi tuntutan yang adil sesuai dengan pertimbangan moral, nilai-nilai agama, keamanan, dan ketertiban umum dalam suatu masyarakat demokratis".

Selain itu, Indonesia juga adalah negara hukum. Pada pasal 1 ayat 3 UUD 1945 ditegaskan bahwa Indonesia adalah negara hukum, negara hukum adalah negara yang

\footnotetext{
${ }^{11}$ Prof Jawahir Tantowi. Islam Politik Dan Hukum, Yogyakarta: Madyan Press Yogyakarta, 2002, Hlm 288

${ }^{12} \mathrm{Http}$ //Www.Mahkamahkonstitusi.Go.Id/Index.Php?Page=Website.Beritainternallengkap\&Id=3941, $\quad$ Akses Rabu 11 Januri 2012
} 
berlandaskan hukum dan yang menjamin keadilan bagin warganya. Maksudnya adalah segala kewenangan dan tindakan alat-alat perlengkapan negara atau penguasa, semata-mata berdasarkan hukum atau dengan kata lain diatur oleh hukum. Hal yang demikian akan mencerminkan keadilan bagi pergaulan hidup warganya. ${ }^{13}$

Pada Hierarkie Peraturan Perundang Undangan No 12 Tahun 2011 menempatkan UUD sebagai konstitusi tertinggi. Maka artinya, undang-undang dibawahnya tidak boleh bertentangan dengan konstitusi yang ada, jika dalam putusan Mahkamah Konstitusi sudah menyatakan bahwa Undang Undang PNPS Nomor 1 tahun 1965 tidak bertentangan dengan konstitusi yang berlaku, maka kedudukan kebebasan beragama yang termuat dalam UUD dan HAM harus tetap dipatuhi sebagaimana termuat dalam undang undang, agar kebebasan tiaptiap individu tidak menjadi sewenang-wenang dalam menasirkan tiap pasalnya.

Ketegasan konstitusi yang sudah mengatur mengenai kebebasan beragama, UU PNPS No 1 tahun 1965 pada pasal 1 juga menyebutkan bahwa, "Setiap orang dilarang dengan sengaja di muka umum menceritakan, menganjurkan atau mengusahakan dukungan umum, untuk melakukan penafsiran tentang sesuatu agama yang dianut di Indonesia atau melakukan kegiatan-kegiatan keagamaan yang menyerupai kegiatan-kegiatan keagamaan dari agama itu, penafsiran dan kegiatan mana menyimpang dari pokok-pokok ajaran agama itu".

Hal tersebut diatas diperkuat dalam pasal 4 yang juga menempatkan pasal 156a KUHP sebagai pijakan hukum dalam penegakkannya, dimana dinyatakan bahwa, "Dipidana dengan pidana penjara selama-lamanya lima tahun barangsiapa dengan sengaja di muka umum mengeluarkan perasaan atau perbuatan: (a) yang pada pokoknya bersifat permusuhan, penyalahgunaan atau penodaan terhadap suatu agama yang dianut di Indonesia, (b) dengan maksud agar orang tidak menganut agama apapun juga, yang bersendikan Ketuhanan Yang Maha Esa”.

Sedangkan pada pasal 2 disebutkan, “(1) Barang siapa melanggar ketentuan tersebut dalam Pasal 1 diberi perintah dan peringatan keras untuk menghentikan perbuatannya itu di dalam suatu keputusan bersama Menteri Agama, Menteri/Jaksa Agung dan Menteri Dalam Negeri. (2) Apabila pelanggaran tersebut dalam ayat 1 dilakukan oleh organisasi atau sesuatu aliran kepercayaan, maka Presiden Republik Indonesia dapat membubarkan organisasi itu dan menyatakan organisasi atau aliran tersebut sebagai organisasi/aliran terlarang, satu dan lain

\footnotetext{
${ }^{13}$ Abu Daud Busroh dan Abu Bukar Busro, 1983, Asas-Asas Hukum Tata Negara, Jakarta, Ghalia Indonesia, Hlm 109
} 
Presiden mendapat pertimbangan dari Menteri Agama, Menteri/Jaksa Agung dan Menteri Dalam Negeri.

Ketentuan yang dengan tegas diatur dalam UU No 1 tahun 1965 itu mengisyaratkan bahwa, ketika pasal 1 dilanggar maka tidak serta-merta pidana itu di jatuhkan, artinya disini Undang Undang dengan sangat baik melakukan tindakan hukumnya dengan memperhatikan berbagai aspek. Misalnya dalam pasal 3 dikatakan, “Apabila setelah dilakukan tindakan oleh Menteri Agama bersama-sama Menteri/Jaksa Agung dan Menteri Dalam Negeri atau oleh Presiden Republik Indonesia menurut ketentuan dalam pasal 2 terhadap orang, Organisasi atau aliran kepercayaan, mereka masih terus melanggar ketentuan dalam pasal 1, maka orang, penganut, anggota dan/atau anggota Pengurus Organisasi yang bersangkutan dari aliran itu dipidana dengan pidana penjara selama-lamanya lima tahun".

Undang Undang memperhatikan pelanggaran penodaan agama dengan bijak. Oleh karenanya, peran pemerintah harus menjadi salah satu factor penentu bagaimana suasana hukum itu akan berjalan nantinya, kewenangan Menteri Agama, Menteri Dalam Negeri dan Jaksa Agung atau yang dikenal dengan SKB (Surat Keputusan Bersama) tiga menteri ini adalah kewenangan yang sah, artinya kewenangan tersebut adalah kewenangan atas pengamanahan yang diberikan oleh undang-undang dan harus di jalankan sebagaimana mestinya.

Ketika Menteri Agama, Menteri Dalam Negeri dan Jaksa Agung tidak dengan tegas menjalankan tugasnya, padahal kenyataannya bahwa aliran sesat begitu menganggu dan berdampak signifikan pada persatuan negera. Maka secara sederhana, bisa ditafsirkan bahwa ketiga lembaga tersebut melakukan pembiaran dan mengabaikan perintah undang-undang. Tapi jika kewenangan tersebut telah dilakukan sebagaimana mestinya tetapi didapati organisasi atau individu masih menjalankan menyebaran aktifitas penodaan agama, maka berlakulah pasal 4 (156a KUHP) UU No 1 tahun 1965, yakni dipenjara maksimal selama lima tahun.

Hal yang menarik dari Psikiater, dokter, sekaligus ustad Prof. Dr. dr. H. Dadang Hawari, beliau mengatakan, bahwa terdapat kelainan jiwa, salah satunya ditandai dengan adanya waham kebesaran dan keagamaan. Waham atau delusi adalah keyakinan yang tidak benar. Meskipun terdapat bukti-bukti tentang ketidakbenaran tersebut, yang bersangkutan tetap meyakininya. Suatu aliran dikatakan sesat, apabila aliran itu menyimpang dari maenstrem agama induknya. Misalnya saja, ayat-ayat Al Qur'an ditafsirkan semaunya, tidak percaya pada hadits, mengkafirkan sesama muslim dan seterusnya, Pemimpin aliran sesat pandai memutar- 
balikkan ayat-ayat dengan logika palsu (pseudo-logika) dalam rangka meyakinkan para pengikutnya. $^{14}$

\section{PENUTUP}

\section{A. KESIMPULAN}

Berdasarkan uraian di atas, maka dapat ditarik kesimpulan sebagai berikut:

1. Bahwa fenomena aliran sesat yang ada di Indonesia sudah hadir sejak lama, oleh karenanya pemerintah harus menaruh perhatian lebih serius, mengingat dasar hokum adalah Undang Undang PNPS No 1 tahun 1965.

2. Bahwa dalam pasal 28 dan 29 UUD 1945 sudah dengan tegas disebutkan bahwa kebebesan yang di amanahkan tersebut dibatasi oleh undang undang lain yang mengaturnya, demi terciptanya keadilan bagi seluruh rakyat Indonesia.

3. Bahwa Undang Undang No 1 tahun 1965 setelah judicial review beberapa waktu lalu, maka undang undang ini masih berlaku, konstitusional dan menjadi salah satu payung hukum yang wajib dipatuhi oleh semua kalangan.

4. Bahwa Undang Undang HAM pada pasal 67 dan 70 juga menjadi pijakan hukum lain yang harus lebih diperhatikan oleh smua kalangan. Mengingat bahwa pokok pikiran para pemohon sering kali mendalilkan bahwa, aliran sesat adalah bagian dari kebebasan beragama.

5. Bahwa Undang Undang No 1 tahun 1965, memberikan amanah yang kuat pada SKB tiga menteri yang terdiri dari Menteri Dalam Negeri, Menteri Agama dan Jaksa Agung, untuk menjalankan tugasnya sebagaimana di atur oleh undang undang, oleh karena itu, organisasi ataupun individu yang melakukan penodaan agama, harus tunduk atas semua ketentuan yang berlaku, khususnya pada Undang Undang PNPS No 1 tahun 65.

\section{B. SARAN}

Maka dari kesimpulan diatas, penulis memberi saran sebagai berikut:

\footnotetext{
${ }^{14} \mathrm{Http} / / /$ Www.Voa-Islam.Com/News/Indonesiana/2012/01/24/17518/Prof-Dadang-Hawari-Pemimpin-AliranSesat-Alami-Gangguan-Jiwa/, Akses Kamis 1 Feb 2012
} 
1. Agar dalam hal ini, Menteri Agama, Menteri Dalam Negeri dan Jaksa Agung untuk dapat lebih tegas lagi dalam menindak tiap pelanggaran yang dilakukan oleh organisasi ataupun individu yang terkait pada penodaan agama.

2. Agar organisasi ataupun individu lebih terbuka dan jernih dalam memahami tiaptiap ketentuan yang mengatur tentang penodaan agama tersebut (Undang Undang PNPS No 1 tahun 1965), karena biar bagaimanapun aturan yang dihadirkan adalah bentuk untuk mencapai tujuan bernegara demi kepastian hokum, kemanfaatan dan keadilan.

3. Agar semua pihak memahami bahwa HAM yang biasanya dijadikan dasar gugatan tiap permasalahan tidaklah berjalan sebebas apa yang di tafsirkan oleh tiap-tiap individu. Kebebasan tersebut adalah dibatasi oleh Undang Undang yang mengaturnya, oleh karenanya tiap orang wajib tunduk pada aturan yang telah berlaku.

\section{Daftar Pustaka}

Undang Undang Dasar 1945

Undang Undang PNPS No. 1 Tahun 1965 Tentang Pencegahan Penyalahgunaan Dan/Atau Penodaan Agama

Undang Undang No 39 Tahun 1999 HAM

Abu Daud Busroh dan Abu Bukar Busro, 1983, Asas-Asas Hukum Tata Negara, Jakarta, Ghalia Indonesia

Moh Mahfud MD, Membagun Politik Hukum, Menegakkan Konstitusi, Jakarta: Rajawali Pers, 2010

Moh Mahfud MD. Membangun Politik Hukum Dan Menegakkan Konstitusi, Jakarta, Rajawali Pers, 2010

Moh. Mahfud Md, "Politik Hukum Di Indoensia”, Jakarta, PT Raja Grafindo Persada, 2012

Prof Jawahir Tantowi. Islam Politik Dan Hukum, Yogyakarta: Madyan Press Yogyakarta, 2002 Kamus Besar Bahasa Indonesia, Balai Pustaka. Jakarta. 1990

$\underline{\text { Http://Www.Mahkamahkonstitusi.Go.Id/Index.Php?Page=Website.Beritainternallengkap\&Id }}$ =3941, Akses Rabu 11 Januri 2012 
Http:/Www.Voa-Islam.Com/News/Indonesiana/2012/01/24/17518/Prof-Dadang-HawariPemimpin-Aliran-Sesat-Alami-Gangguan-Jiwa/, Akses Kamis 1 Feb 2012

MUI: 10 (Sepuluh) Kriteria Aliran Sesat Http://Www.Media-Islam.Or.Id /2007/11/09/MuiSepuluh-Kriteria-Aliran-Sesat/

Maraknya Aliran Sesat Mirip Prolog G30S PKI Tahun 1965 _Http://Hariansib.Com /2007/11/01/ Maraknya -Aliran-Sesat-Mirip-Prolog-G30s-Pki-Tahun-1965/ 